\title{
The Urgency of Digital Media Literacy in Youth Scavengers in Bintara Jaya Environment, Bekasi City, West Java
}

\author{
Dr. Santa Lorita Simamora, M.Si \\ Senior Lecturer in Communication Program, Mercu Buana University, Jakarta, Indonesia \\ Dicky Andika, S.Sos, M.Si \\ Senior Lecturer in Communication Program, Mercu Buana University, Jakarta, Indonesia
}

\begin{abstract}
The purpose of this research is to find out and describe the conditions of teenagers in the scavenger environment regarding their ability to select, filter, sort, understand and evaluate digital media content after they were exposed to current communication technology that transcend the boundaries of social economic status. On the basis that no matter how limited their economic reach are, teenagers in this environment are still exposed to digital media content through their uses of second-hand cellular phones that they bought. This qualitative research approach used a case study method that wants to describe in detail and comprehensively the conditions of this reality.The informants of this research were 4 teenagers who were accommodated by the study group of Sekolah Kami led by Mrs. Irina. These 4 teenagers are part of the 27 youth who are studying in the Sekolah Kami about various skills informally. The research was taken using a purposive sampling technique (as much as it needs), using cellphones. The data was collected using observation and in-depth interviews with informants as well as conducting documentation studies through various documents related to the research theme.The results were analyzed using the qualitative data analysis model from Miles and Huberman. Analysis of the data used stages from this model until there were categories related to the research theme and a conclusion was finally drawn
\end{abstract}

Keywords: Media Literacy, Digital Media, Social Kognitif, The reality of youth scavengers as users of digital media

DOI: $10.7176 / \mathrm{NMMC} / 94-04$

Publication date: December $31^{\text {st }} 2020$

\section{Introduction}

Poverty is the main factor of why teen scavengers exist. Their economic backgrounds and the marginality of their social status forbid them to taste the normal life and formal education. Never mind the education, they are even still struggle to fulfill their daily needs.

Kartono (1990) said that school days is a time that full of turmoil because kids will be facing a lot of problems, challenges, conflicts, and confusions in order to find their place in society. School also have a lot of impact on building one's character and way of thinking because most of children's time will be spent there. But how about them who grew in the slums and couldn't access the formal education? This is the social reality of most children who scavenges around Jakarta.

UU No. 20, 2003, article 3 said that "National education role is to develop the abilities of its citizen and mold their character and civilization to be dignified and to enlighten this nation, it also aim to develop students potential so they could be someone who is faithful and righteous to God, have a good moral, healthy, knowledgeable, handy, creative, independent, and becoming a democratic citizen that responsible"

As we could see from that constitution, it would be difficult for the children who grew in the scavenger environment to follow national education because of their circumstances and also their lack of identity (birth certificate, family card) as one of the requirement for formal education. Even though education is the main way for a healthy character and strong mindset.

A strong country ideally has a strong mental in its generation but if some the youth is in a poor condition (physically, socially, or mentally) how could said country have top quality generation whereas top quality generation is the only one who could continue to fulfill their nation's dream.

Teen scavenger is an abandoned child and a part of a marginalized class. According to UUD 1945, poor people is government's responsibility as said in article 34 "destitute people and abandoned child is looked after by the government". Government have done a lot of programs to fight the poverty but still it's not enough. We could see this from the total amount of abandoned child in streets of big cities, especially after the economy crisis in ' 97 . This abandoned child couldn't get their right of education, health, a place to grow fulfilled. The country need to muster more strength to tackle this problem.

The country haven't seriously tried to take care of this children and we could see this from the condition of slums in Bintara Jaya, Bekasi Jaya, Bekasi City and the teen's lack of education. Their parent's behaviors are also affecting them (from the lack of manner to the absences of religion value). Ironically they lives just beside the modern metropolitan Jakarta. 
It can't be denied that the progress of digital technology has affected many layers in society, from the rich to the poor with various uses according the capability of its user. The ability to choose and filter content in digital media is depends on the user's background, especially education. Many teenagers didn't have the capability to do this. Pornography site, online games, and social media attract their attention and this also happens in the scavenger society. Using the internet healthily is hard to force upon because of its very personal nature. Monitoring and assistance from parents in the scavenger environment is especially hard because it's essentially a self-control thing and the parents lack of ability to filter and choose content that's appropriate for their children. One research about the uses of internet in Yogyakarta by the senior high school student's proved to be shocking because one hundred percents of it's respondant have accessed porn on the internet.( Jurnal Ilmu Komunikasi UPNYK, Vol.16 no. 2 ,2018).

According to Saragih (2018), teenager have a need to get used to using social media in their daily life. Most of them $(93 \%)$ have an average intelligence or knowlodge on how to use digital media properly. Saragih said that most of teenagers have an inherent urge to gain more knowledge and skills, this makes learning new techonology very easy for them. Saragih carried her research in several public school in Jakarta, most of them came from a middle class family. But what about those who came for slums? It's interesting to see if the lower class teenagers would have the same capabilities as their middle class counterparts or not.

Another interesting insight came from Mansur (2019). Her research on social media and its effects on selfidentity development shows that it doesn't actually influence one another. Respondent consideres social media to be helpful on developing their competitiveness, communication skills, and empathy. Again, this result came from teenagers with decent economic backgrounds and enough supervision from their parents. But how about those who live in slums and without proper parenting? They are more exposed to sensitive media and in return it could affect their identity in a different way than those with functional family.

This condition bring us to another problem. Teenagers' lack of ability to filter content in internet gives them easy access to pornography, violence, and hoaxes. These in turn affect their behaviors like free sex, teen marriage, and general lazyness.

Sekolah Kami as a study group was founded by Doctor Irina Amongpraja because of her calling to help the country with helping child scavenger in Bintara Jaya so they could have motivation to study, skills (tailoring, embroidery, soap making, and recyling), religion knowledge, moral, and health knowledge.

The presence of modern communication technology affects everybody no matter how rich or poor they are, educated or not. In the scavenger community, the effect is evident with their teens. Even though they are poor, they still have access to the internet through their cellphones. And it became a problem when their lack of knowledge in the use of internet gave them access to negative content. Because of that, this research will focus on the urgency of digital media literacy for teen scavenger in Bintara Jaya. This research was based on these questions: How is the condition of teen scavenger digital media literacy in Bintara Jaya? Why it's important? And what causes the poor digital media literacy there?

\section{Theoretical Framwork Social cognitive theory}

Social cognitive theory is one of the learning theories that explains patterns in behavior. It is first developed by Albert Bandura in 1960's and focused on how and why people tends to mimic or imitate what they see from media or others. Social cognitive theory developed from social learning theory that laid the groundwork for us to understand, predict, and change human behavior.

Social cognitive theory insisted on our capacity to learn without firsthand experience. Social cognitive theory or as others would call it observational learning theory depends on subject's ability to understand and memorize what they see, identifying using character mediation, and condition or situation that influence the imitating of behavior

Social cognitive theory perspective was born from the critic against behaviorist's theory. Albert Bandura (1986) thought that even if learning principle is enough to explain and predict one's behavior, it still has to pay attention to a phenomenon that is ignored by behaviorism paradigm, that human have ability to think and organize their own behavior. Bandura formulated this theory while accommodating our cognitive capabilities in thinking and learning through social observation. From then on this theory is known as social cognitive theory. This theory is based on a proposition that both social and cognitive progress is central for our understanding on motivation, emotion, and human action. This theory perspective sees that human behavior is a component from a model that interacts with each other and influences situation component and also personal component like affection, emotion, and individual cognitive. Bandura (1986) labeled his theory as social cognitive theory because a couple or reasons. It not only see human cognitive capabilities contribution in motivation process, affection, and action, but also on how they motivates and regulates human behavior and created social systems to organize and structurize their life.

Social cognitive theory focused on our capacity to learn without firsthand experience. Social cognitive theory or observational learning theory depends on subject's ability to understand and memorize what they see, identifying using character mediation, and condition or situation that influence the imitating of behavior. It is often 
used to learn about media and mass communication, health communication, and private or interpersonal communication. Its main purpose is to explain how someone organizes their behavior with control and confirmation or reinforcement to achieve a behavior that's directed to an aim that lasted with time.

\section{Media Literacy}

Literacy, at first refers to someone's ability to read and write letters and numbers in texts or prints. As time goes by, with the development of communication technology and the appearance of many alternative ways to communicate, literacy is now not limited only to written texts but also included sounds, pictures, a combination of both, and many other format in media. Because a lot of communication practice nowadays using those media, we started to call it media literacy.

In many places, efforts to teach media literacy to mass audience generally started because there is a believe that a media could have a significant effect on the masses (Hobbs, 1996:43). Because of that, audiences need to have some sort of skills or competency to fully understand contents in media and this refers to media literacy. But from time to time, media literacy experiences many growths that cause the perspective on the effect of media to be the center focus on responding their roles in our life. It means that media literacy is no longer a means to avoid the negative effects on media, but also a tool for the audience to take benefits from certain content and to use media as a way to communicate.

According to Buckingham (2003: 4), literacy usually refers to a bunch of knowledge and skills that someone has as a result from education process. Education process also gives chances to hone someone's skill to use that knowledge. Human doesn't born with literacy. Someone could naturally have certain skill and competency that allowed him to apply that knowledge with specific way and develop certain ability. But generally knowledge must first be learned and skill must first be practiced. Media literacy widely understood as a knowledge and a bunch of skills that we got from education process called media literacy education.

One of the most widely known definition in academics or media literacy activist circle is umbrella definition'. It is a definition born from National Leadership Conference on Media Literacy in Aspen, USA, 1992. This forum is a meeting between experts and media literacy activist in America that had previously hold media literacy activities before that mostly influenced by the one in England and Canada. This forum produced a formula that reflect a more apparent reality back then and made it more receivable not only in America but also the whole wide world.

Media literacy theorist, W. James Potter proposes a definition for media literacy as "a series of perspective that used actively to face media exposure, interpret, and counter meaning from the message of media" (Porter, 2013:32-33). For Potter, the key to media literacy is on how to build a good structure of knowledge. Those who have it will have a clearer perspective when viewing and distinguishing real world from the in the media, and from that build more favorable life without being influenced by media interest. A more detail explanation about structure of knowledge is intended to reach a deeper understanding of elements that is contained in it and should be one of the most important thing when arranging a curriculum for media literacy education.

According to Potter (2004: 75), there are five elements in the structure of knowledge that underlies someone's literacy of media. These five elements is knowledge regarding the content of the media, knowledge about the media industry, knowledge about the effect of the media, real life information, and self-understanding. The more accurate these things, the higher their potential to be a media literate person. These structure of knowledge give information about media literacy potential but not a guarantee for someone's literacy of media level.

Potential must be realized with individual locus, they must use this knowledge. When someone's locus fully involved, it will gain information from that knowledge structure and make people realized their choices and motivate them to choose a good choices according to that information. The more experience someone have the better their context when processing another new message.

People with lots of knowledge will learn more from media (Comstock, Chaffe, Katzman, McCombs, \& Roberts, 1978); (Ellen, 1981). When someone has a lot of knowledge about certain topic, their knowledge structure will develop well. They usually motivated to obtain further information about various topic and will search a media that could provide it. When they see a new message on a certain topic they will be able to integrate new information quickly and efficiently to the structure of knowledge that they have.

Furthermore, these five elements on knowledge structure is explained succinctly (Potter, 2004: 75-94): 1) Media content. Some people may have a lot of information about the names of TV shows, screenwriters, magazines, characters names, songs, etc. This information helps them access message on media and because of that this type of information is useful. But this type of information doesn't differentiate a media literacy level. To build a significant knowledge structure about the content of media, we need three types of imprtant information: content formula, numbers, and values.2) Media Industry. Generally, someone's knowledge structure about media industry is underdeveloped. They maybe know about the name of papers, magazines, TV stations, and film companies. But usually they only know a little about who own it or how they operate, how they interact within, or how they deliver their message. The deeper and more complex someone's knowledge structure about media industry the more they 
would understand why a certain content is made and why the people in the industry make those choices. There are four field of knowledge that's very important for this: the development of media industry, economy, ownership and control, and marketing message.3) The impact of media. A strong knowledge structure about this element covers three things. One, a wide vision about media effect. Two, people need to understand how these effect happens, and Three, they need to know the factors that is in play here.4) Real life. On many things, media give an accurate information like say from a deep investigation report. For certain things, like information regarding a president, or ministry, etc. media give us information that difficult to gain from other sources. Media could also give bias information about many things and this could be dangerous. If someone's knowledge structure is only consisted of what they got from media it could be said that that structure is dominated by the reality that was created by media. This is the power of the media, we couldn't always compare information from media with the one we got from real life. But if we have a lot of information that we got from real world then our structure of knowledge will be richer and have a comparison.5) Oneself. Someone need to have a strong knowledge structure about themselves: their life purpose, power, weakness, and their style of knowledge. Without this someone would not create a personal locus to control a media message meaning formation. In an attempt to develop their personality, someone will use information that they got from media. Such as making a model based on fictional character or idolizing someone and assosating themselves with them. We could interpret this in a positive or negative light. The most important things is to not get used by media, but use it for their own gain.

\section{Adolescence as User Digital Media}

Adolescence came from the latin word "adolescere" that means growing up to be an adult or in a progress to be one ((Moh. Ali dan Moh. Asrori, 2006: 19). Furthermore, Ali and Asrori (2006:10) emphasized that adolescence is a developmental phase that happens in the middle of potential period whether from the cognitive aspect, emotion, or physical.

Harold, Alberty (in Nurihsan and Agustin, 2013:67) said that adolescence defined as a period in human development that starts at childhood's end until adult. Experts generally use 12 to 21 years of age as a boundary for this phase. Siti Rumini and Siti Sundari (2004: 53-54) defined adolescence as a transitional phase from kids to adults and where a person undergoes development in all aspects and functions. The age period for this phase is 12 to 16 years of age for early adolescence and 17 to 22 years for late adolescence. Some experts have their own variation for this. Monks, Knoers, \& Haditono (in Desmita, 2009: 72) divide it into 4 separate phases: a) Preadolescence or pre-puberty (10 to 12 years old) b) Early adolescence or puberty (12 to 15 years old) c) Mid adolescence (15 to 18 years old) d) Late adolescence (18 to 21 years old).

Adolescence specifically refers to the mid and late stage. According to Mappiere (in Moh. Ali and Moh. Asrori, 2006; Chaplin, J.P, 2011) it happens from 12 years of age to 21 years of age for women and 13 to 22 years of age for man. What we refer to as youth in this research are students of Sekolah Kami study group with age ranging from 13 to 17 years old on scavenger community in Bintara Jaya IV, Bekasi Jaya, Bekasi City. Their grades varied from 7 th to 9 th year.

The advancement of information and communication technology had changed everyone's way of interacting with each other, including youth. Youth, in this context is not constricted to the one with mid and higher social economy but ale include the poorer one like the one on scavenger community in Bintara Jaya IV, Bekasi Jaya, Bekasi city.

The use of digital media (internet, social media) among youth is something unavoidable. Every day they access their social media to look for information from Twitter, Facebook, Instagram, and announce their activity. APJII (Association of Indonesian Internet Provider) published their survey on Mei 2019 that shows from 171.17 internet users in Indonesia, the majority come from 15 to 19 years old, or in this context, youth.

Motivation for children and youth to access internet is to find information, contacting their friends, or looking for entertainment. The search of information is usually for school assignments, whereas the use of social media and entertainment is for their personal need.

\section{Digital Media in nowadays}

Online media or as we usually called it nowadays, Digital Media is a media that's available on the internet. According to M. Romli (2012:34) there are two definitions for it: a) Generally, it's every type or media format that could only be accessed through the internet containing texts, photos, videos, and sound. This definition included email, mailing list, website, blog, Whatsapp, and social media.b) Specifically, it's related with the definition of media in the context of mass communication. Media or mass communication media in communication studies have certain characteristics like publicity and periodicity.

Another name for online media is new media, a media that's based on the internet using computer and sophisticated phone. The main resources for this change are satellite communication and the use of computer. The key for computer prowess as a communication machine lies in the digitalization process that makes it possible for every kind of information send with efficiency and blending in. 
Internet's characteristic features as a media are: a) Computer based technology b) Hybrid characteristics, undedicated, and flexible c) Interactive potential d) Private and public functions e) Loose rules f) Interconnection g) Everywhere h) Accessible by individual as a communicator i) Mass or private media communication, (Potter in McQuail, 2011:151).

\section{Research Methods}

This qualitative research used constructivism paradigm. This paradigm is an antithesis to the tenet that places observation and objectivity to find a reality or science. This paradigm sees social science as a systematic analysis of socially meaningful action through direct and detailed observation towards social behavior of someone that create and maintain their social world.

According to Patton (1978), contructivist studies many realities that constructed individuals and the implication from those constructs for their lifes and others. In constructivism, every person has their own unique experience. With that, research with this strategy suggest that every views that someone uses to see their world is valid and there is a need for mutual respect for that.

Contructivism paradigm has certain criteria that distinguish it from other paradigm that is ontology, epistemology, and methodology. In ontology level, contructivism paradigm sees reality as real but complex and has different meaning for each people. In epistemology, researcher used a subjective approach, with this, they could explain a construction of meaning by individual. In methodology, this paradigm uses many types of construction and combined them into a consensus. This process involves two aspects: hermeneutic and dialectic. Hermenutic is an activity of writing text - conversation, article, or picture, whereas dialectic is the use of dialogue as an approach so the thought of the subject for the research could be reviewed and compared to the thought of the researcher. With this, the harmony of communication and interaction could be reached maximally.

The method of this research is case study. Casswell (2010) explained that case study is a method that used to investigate and understand an event or problem that had happened through the collection of informations that then will be processed to gain a solution for that problem. Susilo Rahardjo \& Gudnanto (2011) also explained that case study is a method to gain an understanding of an individual that was done integratively and comprehensively to achieved a deep understanding about that individual and gain a positive self-developtment.

In scientific tradition, qualitative research categorized case study as one of it's research type. Case study was interpreted as a method or strategy in a research to reveal particural case. Another definition explained it as the result of a research on a certain case. The first definition refer to the strategy of the research and the second on its result. In this writing we will follow the first one.

Case study research focused on one particular object that hailed as case and will be dissected thoroughly to reveal the reality contained within its phenomenon. It is because something that is visible doesn't necessarily mean it is real (reality). It is only a reflection from something within.

Just like another data acquisition method in qualitative research, the data of a case study could come from every involved party, whether it is from a deep interview, observation, participation, and documentation. In essence, every data obtained from various sources would complement each other. There are times when the data obtained from an interview alone would not be enough so a researcher must obtain it from another sources.

In comparison with quantitative research method that emphasizes on numbers or sample quantity from researched population, a case study research accentuate the depth of the problem that it observe. Because of this, case study method must be done intensively, detailed, and profound.

Writers used a couple of methods to obtain data for this research like triangulation or combining various techniques with an in-depth interview. In-depth interview was done by asking a couple of questions to the informant with or without a guide where the interviewer and interviewee could tangle in a relatively similar social life (Sutopo 2006: 72). The in-depth interview for this research was carried out in teenage scavengers environment in Bintara Jaya, Bekasi Jaya, Bekasi City.

Writers also directly observed the location for the research. Observation is a sighting activity using researcher senses and was planned, done systematically, and have it result noted to be interpreted for the sole purpose of gaining understanding about the object that being observed upon. Observation was also done when the researcher having a conversation with the informant. In this context, the informants were five teenagers that lives in Bintara Jaya and participates in Sekolah Kami study group. In-depth interview was also done with key informants (someone who fully understand the situation or problem that being researched), who in this case is the Head of Sekolah Kami study group, Irina and a volunteer teacher, Tatiana. Using in-depth interview, writers obtained primary information through our interactions.

The observation technique is one of the qualitative research data acquisition method that is recommended for obtaining descriptive data. Observation used to comprehend pattern, norm, and the meaning of behavior from the informant. There are two types of observation, participative observation and non-participative observation. Participative observation must be done while actively engage with the informant's life. This research was done non- participatively and only observed the activity of the informant in Sekolah Kami from the sidelines. 
Writes also used document study technique for this research. The document used in particular is the track record document that Sekolah Kami had.

We used purposive sampling to choose our informant. Herdiansyah (2012) explained that purposive sampling is a technique in nonprobability sampling and based its selection on characteristic features that the subject have in accordance with the purpose of the research. The informants in this research are five teenagers from the age of thirteen to seventeen years that studies in Sekolah Kami and also works as scavengers and have access to digital media through their Android phone and lives in Bintara Jaya, Bekasi City.

An overview on the urgency of digital literacy among teenage scavengers was based on our observation in the field. The data acquistion method we used was triangulation or combining several techniques to get primary and secondary data. The primary data was from our interview and observation on the research objects that have been purposively selected. Our secondary data we got from documentation study through elaboration with many writings that have relation with our theme.

After we compiled it and got the saturated data, writers started to analyze it with Haberman and Miles model. There are three steps for this model:1) Data Reduction Stage, Several analysis steps when collecting data according to Miles and Huberman is: sum it up, code it, classify it, and then label it. Researcher is obliged to reduce their data independently in order to gain data that could answer research question.2) Data Presentation / Data Analysis After Collection Stage, In this step researcher mainly involved on data presentation using the one that have been analyzed before and given that qualitative researcher must write a lot of narrative texts. It was displayed in a format that present the information thematically to the reader. Miles and Huberman (1984) introduced two formats: context chart and matrixes.3) Conlusions and Verification Stage, The next step is drawing conclusions based on findings and verifying it. The early conclusions before is only temporary and could change following new findings that is stronger than the first one. The proses of finding proof is what's called data verification. If what was concluded in the beginning of the research was supported by proofs that would remain consistent when the researcher return to the field then that conclusion is credible

Analysis and data triangulation was also used to test the validity of the data and find the most objective truth. This method is truly fit for analyzing a certain event in a certain place and a certain time. Descriptive is a method on researching a group of people, an object, a condition, a system of thought, or current occasion.

For a qualitative research to be good, Poerwandari (2001:102-106) said that five criteria must be met: First, openness or the intensity of the researcher while discussing their research with another person that was considered as an expert on those subject. Second, conformity or the willingness of the researcher to openly explain the process and elements of their research so that another person could also collaborate in it. Third, truth. This refers to the truth that was influenced by the perspective of the one that was involved with it and because of that it depends on the context of the situation and the one that define it. Fourth, credibility. It reside in the success of attaining meaning, the ablity explore a problem, describing setting, process, social group, or a complex interaction patterns. Researcher successed in gaining all information in one interview. The last criteria is transferbility or how much a research that was done on one group could be applied on another one that's relevant.

Norman K. Denzin (2009:523) defined triangulation as a combination of several methods that was used to examine phenomenon that is interrelated from different perspective and point of view. Until this day, this concept is still used by qualitative researchers in many fields. According to him, triangulation covers four matters: (1) triangulation method, (2) triangulation between researcher (if the research was done in groups), (3) triangulation of the source, and (4) triangulation theory. The explanation is as follows:

Triangulation method was done by comparing information or data with different methods. In qualitative research, researcher uses interview, observation, and survey. In order to gain accurate information and a clearer picture on something, researcher could use free interview method or structured interview method. Or, the researcher could use interview and observation or surveillance to check the fact. Other than that, the researcher could use a different informant to test the credibility of that information. Through different perspectives it is expected for that information to be closer to the truth as possible. Because of that, this triangulation step was done only when there is a doubt on information that came from an informant or subject. A clear data like texts, script/transcript, novel, etc. doesn't need triangulation. However, triangulation aspect must still need to be done.

Triangulation between researchers was done by using more than one person when collecting and analyzing data. This technique was recognized to be able to enrich knowledge about the information that is being dug. It is important to note that the person who was invited to participate in that research needs to have certain knowledge about researching and free from conflict of interest to avoid new bias in triangulation.

Triangulation of the source is digging in order to gain the truth through various method and resource. For example, other than interviews and observations, researchers could use participant observation, documents, archives, history texts, official notes, diaries, pictures, or photos. Of course, each source could produce different proofs or data that could also give different insights about one phenomenon. Different perspectives would bring forth a vast amount of knowledge that could be used to reach the truth.

The last one is triangulation of theory. The final result for a qualitative research is a thesis statement. This 
information then will be compared with relevant theory perspective to avoid individual bias. Other than that, triangulation of theory could increase the depth of understanding as long as the researcher could dig theoretic knowledge of the analysis result from the gained data. This is the most difficult step because a researcher was obliged to have an expert judgment when comparing their result with certain perspective. More so if the comparison result is different.

Triangulation becomes really important in qualitative research, even if it means more time, cost, and effort. However it must be admitted that triangulation could also increase the understanding of the researcher regarding the phenomenon or the context behind it. Deep understanding of the researched phenomenon is an important value for every qualitative researcher because qualitative research was born to catch the meaning behind phenomenon, event, fact, incident, reality, and certain problem about social events and the complexity of humanity, and not to explain the connection between variables or to prove a cause and effect, or correlation between certain problems. Deep understanding could only be reached after gaining a lot of data and various perspectives that will be used to capture the focus of a problem comprehensively. In this research context, writers used two triangulation, the first and the fourth.

\section{Research Results and Discussion}

"Sekolah Kami" study group was founded in 2001 while moving from place to place for at least 3 times and now they could rent a space in scavenger's slum at Bintara Jaya IV, Bekasi City. Sekolah Kami is a study group that was founded for children scavengers and other poor people in scavenger's community at Bintara Jaya, the place have been rented by Irina since 2007. Now it accommodates about 125 students from the first to tenth grade. In 2019, Sekolah Kami successfully collaborates with a private school for senior high school.

Their study time only lasts for four hours per day, from eight in the morning until twelve. After that they have to help their parents scavenging. Apart from giving elementary lectures, Sekolah Kami also teach them various skills like how to make a soap, a paper, how to sew, gardening, play music, and making several handicrafts from scraps.

Dr. Irina got their funds mostly from private donation. Sales from student handicrafts also returned to them in form of savings for the school operational cost.

Irina Among Praja never imagined that Sekolah Kami could graduate hundreds of childrens. It just went along with the flow, never having been imagined that it would stand for this long. Irina realized that she doesn't have any educational background before at managing a school, even if it is an informal one.

According to her, at first she was did it on a whim, but then she became curious and finally felt that she was destined to manage Sekolah Kami. She observed that scavenger's children doesn't see school as something important, this in return motivated her to persuade and direct this children to study, she facilitated them so the children at Bintara Jaya could learn freely. Her effort was a success; she persuaded their parents that school is important. A new problem arise when they started to study, a formal document was needed for this children to access various formal education programs.

Beside that problem, many youths also forced to married after they are done with their education in junior high school or even elementary so they could ease the burden of their family. The educators at Sekolah Kami felt that their program was a failure after seeing this, especially for their female students that have to obey their parents. This condition reflected their disbelief in waiting for education process in Sekolah Kami.

Over time, the students of Sekolah Kami grew from scavenger's child to other children who couldn't attend a formal school like the child of peddlers, the child of taxibike drivers, and the child of maids, with the child of scavengers as the majority.

Sekolah Kami teaches many skills like crafting things from scraps, making soaps for wedding souvenir, and sewing. Several people have ordered their products for souvenir. Surprinsingly, Sekolah Kami have also receive orders from as far as Netherlands for handicrafts made from scraps.

The wish of the educators of Sekolah Kami is not complex; they didn't even expected their students to continue their education to senior high school. After graduated from Sekolah Kami, the students were supported to take A Package exam. If succeed, they then will be schooled at 252 Open Junior High School and then after that trained for six months in Balai Latihan Kerja (BLK). The result, several students completed the training and could work at confection company or beauty salon.

According to Irina, the most difficult challenge in educating these children at Sekolah Kami is changing their mindset and behavior. When first joining Sekolah Kami, some of them was asked about their future goals or dream, most of them answered that they want to have a bigger cart or become the boss of scavengers. This shows just how limited their views are, only around their environment in waste disposal sector.

The teachers also often have to cope with student's parents and their behavior at home. For example, the courtesy that the student got from lectures gone when they go home because their parent doesn't know about any of those. Problem arise after a long holiday when the students forgot what they have learned from school because during their time at home, their parents doesn't teach them again. 
One of Sekolah Kami's teacher, Tatiana, explained that the education process in Sekolah Kami couldn't be compared to another formal school or private school where the student came from normal family. According to Ririn, the school management still refers to formal curriculum but there are several modifications that have to customize following student's personality.

This is because the students of Sekolah Kami came from families whose parents doesn't see education as a needs for their kids. Because of that, Sekolah Kami is more concerned to teach manner and building characters for their students. Thanks to their perseverance, now they could read and write and also absorbing lesson like another kids at normal school.

The lesson that was given to the students was tailored according to their capabilities, some of them even illiterate at first. According to the team from Sekolah Kami, their effort has bore fruits. The students of Irina and co. now have manners and full of confidence, skilled, and happy to help. Now their dreams and goals have expanded like normal kids, they want to continue their education. When asked some of them wants to be a teacher, and some even wants to be a soldier. Irina and her team hope that some of their students could get a chance to attenduniversity.

Because the student at Sekolah Kami came from imporvished family, the curriculum there combines formal lesson with skills lesson. Their status as a child of a poor family makes it hard for the team to instill a sense of wanting to learn and continue their education.

The students there also don't concentrated on formal education like a normal school. This was done to accommodate their background and so they could be more comfortable at school. Sekolah Kami is more focused on teaching character so the student could be a confident, honest, and skilled graduate.

In order to make a positive character, Sekolah Kami also use religion approach. After Shalat (praying), the kids were taught to do other minor prayers like Shalat Sunnah (uncompulsory Shalat) before class. This was done to develop their morals and manners.

Sekolah Kami located in slums at Bintara Jaya, Bekasi City. The majority of the populace there works as scavengers and came from Kerawang and Kuningan. Scanvengers in Bintara Jaya IV is not a legitimate inhabitant or local because most of them don't even have official identity.

Besides that, they came from improvised family and don't even have any legitimate identities, this barred them from attending formal school. They studies at Sekolah Kami from 8 a.m. to 12 p.m., after that they help their parents scavenging scraps. When free from their work, they usually stays at their home watching TV or surfing the web for those who have the gadget for it.

Their economy limitations doesn't stop them from owning phone, they are saving money from working with scraps a buys a used one. The lack of education and wealth from their parents resulted in the lack of education regarding digital literacy in this digital age.

Most of the parents only finished elementary school, some of them doesn't even schooled at all, this resulted in the lack of motivation to teach their child digital literacy skills. They don't understand what and how media could affect them, moreover teach their children about it.

Their inability as parents that lack any knowledge and skills in understanding digital technology hinders them in accompanying their children interacts with digital media like phones. The interaction between teenage scavengers and phones is keep rising following the common trends in society. For them, surfing the web give them unique pleasure because they could learn or know new things that they never seen before. Just like what one of our informant, V, said: "Sophisticated phone allowed me to be acquainted with lots of friend; I could also own my own Instagram where I could upload my daily activities. I could also know what is trending among youths nowadays."

That's what Vira said when we interviewed her during community service that was being done by Public Relations Department of Communication Studies Faculty of Mercu Buana at Sekolah Kami, Ramadhan of 2019 ago. The theme of this event is youth literacy of digital media.

Parents who gave birth to their children in this digital age is obliged to understand and follow its development including the development of the internet and the development of gadgets. But the conditions of the scavengers that don't understand communication technology or "gaptek" hinder them to learn about Facebook, Twitter, Instagram, and Vlog. This conditions disallowed them to accompany their children when surfing the web.

Teenage scavengers usually use their phones after they come home from school or when they are done helping their parents scavenging scraps. When surfing the web they usually do it alone or together with their friends. Nobody oversee or guide them when surfing the web so what they accessed was unfiltered.

As the times goes along with the development of communication technology human could interact with each other using social media like WhatsApp, Facebook, Instagram, and YouTube. Teens nowadays could communicate without being confined by space and time only depend on their own self as the one who operate it. This luxury could be felt affected their way of life. Moreover now various applications and interesting features has emerged like many entertainment and games that could be played using smartphones. This phenomenon happens to every layers of youth without seeing their social and economic background, the teenage at scavengers community also being affected by this new lifestyle of using smartphone and enjoys surfing the internet. 
Teenage students of Sekolah Kami study group that have phone usually access internet in their home or around scavenger's neighborhood in Bintara Jaya IV. When studying at school they are prohibited from bringing or using phone. At school, teenage students haven't been taught routinely about computer technology and internet because Sekolah Kami couldn't afford to facilitate computer for their students. But the teachers keep reminding their students to be careful when surfing the web through their phone, even though the teacher couldn't keep an eye on them for 24 hours.

Smartphones usage among teenagers is quite high. Informants told us that they use smartphones to follow the trends among youths. Generally they use social media like Whats App, Facebook, Instagram, and YouTube because they are oriented to personally communicate and related to their peers or people of the same age. Next is the result of our interview with three informants (I, J, and $\mathrm{K}$ ) on why they decided to use those social media.

From those interviews we could see that the informants indirectly chose to own a social media so they could be seen just like other normal teenagers, communicate with their peers in cyberspaces. They stated that they use the internet to looking for information, communicate with their friends (new or old), and for their own amusement. They use social media so they could relate with their friends and see a lot of things on the internet. "I usually use Facebook because there are a lot of friends that send me messages or friend invitations" (Informant I). "Because a lot of my friends also use Facebook, there we could communicate with each other" (Informan J). "Using Facebook because I still have needs there" (Informant K).

Social media features in smartphones are one of the main factors of smartphone addiction among teenage scavengers. Overuse of smartphones among them resulted in psychological problems. Social media overuse goads them to access porn, playing online games, and games with adult element on them. Things got worse because it is difficult to control their enthusiasm on smartphone and its interesting features. Various features and designs from smartphone provide enough attraction for teenage scavengers. Their immature psychological development couldn't help them to filter internet contents and to determine which content that suitable for them and which one who is not like pornography.

Informants acknowledge that through social media they could know a lot of modern things, like from Instagram they could see a lot of pictures or videos from popular people, they could also follow the current trends among modern teens, they stated that they are not active on Instagram, most of them only follows other people account so they could be considered cool. Cool for them is following the trends and not being called unpopular.

Teenage doesn't have any awareness about the negative impact of smartphone overuse. Their ability to control and minimalizing smartphone usage and social media is still low. Besides that, they didn't get any guidance from their parents about it. At home they feel that their parents doesn't give them enough attention because they are too busy searching for scraps. Teachers only give them guidance when they are at school. They doesn't have any ability to manage their time on when to use smartphone. This is all because they doesn't have digital media literacy.

Informants indirectly chose to own social media account like Whats App, Instagram, and Facebook because they are interested in communicate with their peers at the internet. They stated that when they communicate with their friends and other people on the internet the feel more confident. This is similar to what Kunst said about individual value. Individual value (Gudykunst, 2002: 225) is personality values that every individual have in order to maintain and keep their confidence when communicate with other people. When using social media like Whats App, Instagram, and Facebook, informants displayed their own unique personal values.

Indonesian government through the Ministry of Communication and Information Technology (Kominfo) have tried to restrict the distribution of pornography content with blocking several porn sites using the Internet Positif program, they also blocked other harmful sites besides pornography. But this effort seems fruitless with the emergence of several tutorials on the internet on how to bypass this blockade. Another content that teens frequently uses, online games, also have several pornography aspects in form of how the women dresses. On the internet, the chances to do this activity and access them are very open. This in return make teens forgot to study because they spends too much time on their phone and internet.

A theory by Albert Bandura explained about how and why people tend to imitate what they see from media or other people. This could also happen to the students of Sekolah Kami that accessed pornography through smartphone. There are teenage scavengers that emulate this content and produce a free sex behavior. This is not the sole cause of free sex behavior among them; another factor like seeing their parents having sex in their inhospitable house could also cause it. Just like what Bandura said, what the youth see would be an example of how they will behave, especially from their parents.

\section{Conclusion}

The result of the research about the urgency of literacy among teenage scavengers that use smartphone shows that:

1. The Teens shows behavior that they wanted to be seen as other normal teenagers that use smartphone and access social media.

2. Personally, they use social media because they want to communicate with their friends. So they decided to create more than one social media account. 
3. Teenagers imitate behaviors in pornography that they see through smartphone.

4. Teenagers doesn't have a capability to filter and sort suitable and unsuitable content for themselves.

\section{Limitations of Research}

The result of this study have not yet gotten to describe the urgency of digital media literacy in youth scavengers in Bintara Jaya Environment, Bekasi City, West Java overall. Therefore research needs to be carried out with other approaches and in several broader and different areas. So that the data describing the urgency of digital media literacy in youth scavengers is more complete.

\section{References}

Barker, Chris. 2008. Cultural Stydies Teori \& Praktek. Yogyakarta. Kreasi Wacana Bandura. (2005). Social Cognitive Theory. New Jersey. Pretice Halls, Inc.

Buckingham, David (2003). Media Education: Literacy, Learning and Contenporary Culture. Cambridge UK: Polity Press.

Cris Barker, Cultural Studies: Teori dan Praktik (Yogyakarta: PT. Bentang Pustaka), 221. Chaplin. J.P. 2005, Kamus Lengkap Psikologi, Jakarta, Raja Grafindo Persada. Hal.250. Carole Wade dan Carol Tavris. Psikologi, edisi ke 9, Penerbit Erlangga 2007, 309

Cris Barker, Cultural Studies Teori dan Praktik, (Yoyakarta: PT. Bentang Pustaka), 221. Depdiknas, Undangundang SISDIKNAS, Jakarta: Fokusmedia, 2000.

Desmita.2009. Psikologi Perkembangan Peserta Didik. Bandung : PT Remaja Rosdakarya.

Dariyo, Agoes. 2007. Psikologi Perkembangan anak usia tiga tahun pertama, Jakarta; PT Refika Aditama. Hal. 205

Dedy N. Hidayat. 2003. Paradigma dan Metodologi Penelitian Sosial Empirik Klasik, Jakarta : Departemen Ilmu Komunikasi FISIP Universitas Indonesia.

Effendy, Onong Uchjana. 2008. Ilmu Komunikasi, Teori \& Praktik. Bandung : PT. Remaja Rosdakarya

Gudykunst, William B dan Bella Mody, 2002, Handbook of International and Intercultural Communication 2nd Edition, United States of Amerika, Sage.

Hobbs, R (1996), Media literacy, Media activism, Telemedium, the journal of media literacy Hurlock. E. Adolescent Development, (4 ${ }^{\text {th }}$ ed.) (Internal Student Edition). 1979.Hal.434 Hurlock, E. (1978). Personality development. Tokyo: McGraw-Hill Publishing Company, Ltd.

Herdiansyah, H. (2012). Metodologi Penelitian Kualitatif untuk IlmuIlmu Sosial. Jakarta: Salemba Humanika.

H.B. Sutopo (2006). Metodologi Penelitian Kualitatif : Dasar teori dan Terapannya dalam Penelitian Surakarta: Universitas Sebelas Maret.

Jurnal IPTEK-KOM, Vol. 15 No. 1 Juni 2013: 47-62

Jurnal Pengabdian Kepada Masyarakat Unpad Vol. 1, No. 1, Februari 2017: 35 - 40 Kartono, K., (1990). Psikologi Anak. Bandung : Mandar Maju.

Michael A Hogg., The Social Identity Prespective: Intergroup Relation, Self-Conception, and Small Group, Sall Group Research, Vol 35 No.3,( June 2004), 254.,pdf

Miles, M.B \& Humberman, A.M. (1992). Analisis data kualitatif: buku sumber tentang metode- metode baru. Terjemahan oleh Tjetjep Rohendi Rohidi dari judul Qualitative Data Analysis. Jakarta : Universitas Indonesia Press.

Moh. Ali dan Moh. Ansori. (2006). Psikologi Remaja: Perkembangan Peserta Didik. Jakarta: BumiAksara

M.Romli, Asep Syamsul. Jurnalistik Online: Panduan Praktis Mengelola Media Online (Bandung, Nuansa Cendekia, 2012) Hal 34

Larry A. Samosir. Dkk Komunikasi Lintas Budaya, edisi 7, Salemba Humanika. 2010), 197.

Mansur, Suraya. 2019, Social Media Shapes Youth's Identity and Self Concept in Sawarna, Lebak Banten, Indonesia, accessed from International Journal of Scientific and Research Publications, Volume 9, Issue 7, July 2019869 ISSN 2250-3153.

Michael, AHogg,. The Social Identity Prespective: Intergroup Relation. Self-Conception, and Small Group,Sall Group Research, Vol 35 No. 3 June 2004. (Sage Publication, 2004). 25

Milles, M.B. and Huberman, M.A. 1984. Qualitative Data Analysis. London: Sage Publication. Muhammad Nazir, 1988, Metode Penelitian, Ghalia Indonesia, Jakarta.

Norman K. Denzin, Handbook of Qualitative Research Edisi Bahasa Indonesia oleh patricia A. Adler dan Peter Adler (Yogyakarta : Pustaka Pelajar, 2009), hlm. 523

Potter, W. J. 2008. Media Literacy: Fourth Edition. Thousand Oaks: Sage Publication.

Saragih, Nurhayani. 2018, Keterampilan Penggunaan Media Sosial Remaja Ibu Kota. Accessed from http://digilib.mercubuana.ac.id/manager/t!@file_artikel_abstrak/Isi_Artikel_866560899016.pdf

Melalui Siti Rumini dan Siti Sundari. (2004). Perkembangan Anak dan Remaja. Jakarta: Rineka Cipta. Sunarjo dan Djonaesih S. Sunarjo.1983. Komunikasi Persuasif dan Retorika. Yogyakarta : Liberty Saputra, Wahidin. 
2011. Pengantar Ilmu Dakwah. Jakarta: PT. Raja Grafindo Persada.

Tim Penulis Fakultas Psikologi UI, Psikologi Sosial, (Jakarta: Salemba Humanika, 2009), 55-56 Widjaja, A.W.1986. Komunikasi dan Hubungan Masyarakat. Jakarta : Bumi Aksara 